\title{
The American-German Partnership in the Early Twenty-First Century: A New Challenge
}

\section{Vladislav V. Froltsov*}

Based on recent political events and an analysis of a range of articles by German experts in the field of global politics, this essay will define the main preconditions for the deterioration of American-German relations in the early 2000s. From there, it will go on to outline the most probable scenarios for the further developments in the political interaction of these nations.

One of the most salient issues of modern European and transatlantic politics is the development of relations between the United States and Germany. During the postWorld War II years, these states were the closest allies, a relationship that allowed the successful containment of Soviet pressure against Western Europe. The well-known words of President J.F. Kennedy- "Ich bin ein Berliner"-which were spoken in June 1963 (two years after the construction of the Berlin Wall) ${ }^{1}$ can be looked to as the slogan of the American-German partnership in the sphere of defense and security in the following decades.

It is necessary also to emphasize a key role of the U.S. during the process of German unification. The consistent position of the first President Bush, who supported the Federal Republic of Germany's plan to gradually incorporate the GDR into the FRG, helped convince Mikhail Gorbachev to agree with this approach. If the position of the former American president had not been as firm, the Soviet Union could have proposed the slowest speed of integration possible, and thus have created $a$ de facto longterm conservation of the pro-Soviet regime in East Germany. Therefore, Helmut Kohl, the former Chancellor of Germany, has characterized his American colleague as "a great stroke of luck for us Germans" ("ein grosser Glücksfall für uns Deutsche"). ${ }^{2}$

A result of such close cooperation between the U.S. and Germany in 1989-90 was the rebuilding of the united German state, its further full membership in NATO, and the strengthening of the German role in the system of European and transatlantic security more generally. Moreover, in the 1990s Washington successfully promoted the return of a united Germany to major-power status in international politics, a nation able to actively participate in peacekeeping operations around the world. After the decision of the Bundesverfassungsgericht (the High Constitutional Court of Germany) to permit the Bundeswehr to participate in peacekeeping missions out of the area of NATO responsibility in July 1994, ${ }^{3}$ soldiers of the Bundeswehr took part in such missions as

* Dr. Vladislav V. Froltsov is Associate Professor in the Department of International Relations, Belarusian State University, Belarus.

1 Manfred Görtemaker, Kleine Geschichte der Bundesrepublik Deutschland (Bonn, 2002), 152.

2 Helmut Kohl, Ich wollte Deutschlands Einheit, eds. Kai Diekmann and Ralf Georg Reuth (München, 2000), 166.

3 Görtemaker, Kleine Geschichte, 391. 
ISAF, KFOR, SFOR, Task Force Fox, UNOMIG (Georgia), and Operation Enduring Freedom.

The U.S. also welcomed the German willingness to accept status as one of the key guarantors (together with the Netherlands) of peace and stability in Afghanistan. In February 2003, these countries took command of the multinational ISAF force in postTaliban Afghanistan. At present, Germany has the largest military contingent (2500 soldiers and officers) in the field under the framework of this peacekeeping mission. ${ }^{4}$

Thus, in the early 2000s, almost 10,000 German soldiers were quartered outside of Germany. This circumstance, however, did not give rise to discussions of "the Revival of German Militarism," either in declarations by American politicians or in the American mass media, even though the current German military currently maintains a presence in those regions that are especially important for the national security of the United States. But a hypothesis about the "Germanization" of the Balkans and the Middle East has found fertile soil in some academic centers and mass media in Russia and other CIS countries.

Another situation has developed around the military action of the U.S. and their allies in Iraq. This operation caused a discussion among German scholars of world politics about the danger of American unilateralism to the state of modern international relations. It is remarkable that one of these experts, Dr. Jochen Hippler, from the University of Duisburg, has entitled an article "U.S. Unilateralism as a Problem of International Politics" ("Unilateralismus der USA als Problem der internationalen Politik"). He writes that this problem was created first of all by the fact that the U.S. ignored the norms of contemporary international law, as well as the Status of the United Nations as a key structure, which is responsible for the Peacekeeping and Stability around the World. ${ }^{5}$

The title of an article by Gert Krell, a professor at Johann Wolfgang University in Frankfurt am Main, entitled "The Arrogance of Power, The Arrogance of Powerlessness" (“Arroganz der Macht, Arroganz der Ohnmacht”) is no less explicit. In this essay, the author emphasizes that the main problem in the current arena of transatlantic relations is a divergence vision between the representatives of the elites of two countries regarding the future of world politics and international law. This divergence, and the risks it poses is particularly illustrated by the German response to U.S. actions in Iraq, which, in the author's words, will lead to the 'Liberation' of Iraq (in a similarly ironic manner, Krell describes the German word "Befreiung" as "so-called"). ${ }^{6}$

Nevertheless, the author recognizes that at this moment the European countries are not able to oppose the U.S. by positing an alternative foreign policy strategy towards

4 Axel Vornbäumen, "Teamarbeit," Deutschland (2003), 34-35; Annette Blettner, "Bundeswehr Einsatz in Afghanistan," Deutschland (2003), 58-61.

5 Jochen Hippler, "Unilateralismus der USA als Problem der internationalen Politik," Aus Politik und Zeitgeschichte 31-32 (2003): 15, 17-18.

6 Gert Krell, "Arroganz der Macht, Arroganz der Ohnmacht," Aus Politik und Zeitgeschichte 31-32 (2003): 29. 
Iraq and other troubled regions of the world. Krell characterized this problem as the "powerlessness" of Europe in comparison with the "power" of the United States.

In reply to this hypothesis, two scholars at the Hessischen Stiftung Friedens-und Konfliktforschung (HSFK), Dr. Matthias Dembinski and Dr. Wolfgang Wagner, declared that American policy in Iraq is a "challenge" ("Herausforderung") to the European Common Foreign and Security Policy (CFSP). They recalled also the 1999 plan to create a 60,000-man European Crisis Prevention Force, which, however, still does not exist. ${ }^{8}$

Thus, these authors emphasize that the formation of the CFSP will be the most burning issue for EU members, as some European states have diametrically opposed positions towards the problem of Iraq, namely the countries of the so-called "Old" and "New" Europe. This statement was caused by the position of the new members of the EU (Poland, Hungary, Czech Republic, Slovenia, Slovakia, and the Baltic states) and the candidates for the next round of EU membership (Albania, Bulgaria, Croatia, Romania, and Macedonia).

But the conflict concerning allied military action in Iraq within the ranks of the "old" EU members - namely between Germany, France, and Belgium and Great Britain, Italy, and Spain (until the results of a recent parliamentary election) - is no less important for the future of the CFSP. And many members of the EU preferred to take a neutral position, which can be interpreted as a less than resounding vote in favor of further European cooperation in the area of security and defense.

Therefore, the reproach of the German Ambassador to the United Nations, Gunther Pleuger, in an interview for a governmental magazine Deutschland seems more than doubtful. He said that the U.S. does not wish to include the representative of the EU on the Security Council of the UN as a permanent member. ${ }^{9}$ But if, hypothetically, this representative had been in Washington in the first weeks of 2003 at exactly the moment of a decision concerning Iraq, it is almost impossible to forecast what position he would have taken, given the widely divergent points of view towards the Iraq problem that currently exist between the current EU members.

Other German authors are less critical regarding U.S. foreign policy. They propose various strategies for future German foreign policy, but some of them can be evaluated as quite fantastic. For example, the journalist Jochen Thies believes that, given the conditions of disagreement with the U.S., Germany should concentrate on solving European problems. Namely, Germany could promote a stabilization of the political situation in the Balkans. Nevertheless, he recognized that for the realization of this goal it would be necessary (at the very least!) to reconstruct the Bundeswehr according

7 Ibid., 30.

8 Matthias Dembinski and Wolfgang Wagner, "Europäische Kollateralschäden," Aus Politik und Zeitgeschichte 31-32 (2003): 31.

9 Gunther Pleuger, Interview, Deutschland (2003), 57. 
to the American model and, first of all, to borrow from the U.S. the principle of the professional army. ${ }^{10}$

But it is almost impossible to achieve this goal in modern Germany under current conditions, which are characterized by the significant strengthening of pacifist and anti-war moods in German society after the military actions in Kosovo and Iraq. A certain segment of the German people (approximately 15 percent), which voted in 2002 for the Left Socialists (the PDS) and the Greens, is prepared today (or in the near future) to liquidate both the German Army (Bundeswehr) and NATO. Moreover, these slogans and promises are part of the current platforms of PDS and the Greens. ${ }^{11}$ It is remarkable that the Greens are not only a ruling party today, but the party's leader J. Fisher personifies the present German diplomatic function.

Joachim Krause proposed a more realistic approach to the normalization of the current situation in American-German relations. He called on both Europeans and Americans to continue a dialogue about the Iraq problem and other urgent questions in international relations. In his opinion, such a transatlantic dialogue will be a major element of any effective strategy of peacekeeping and stability around the world in the coming decades. And this dialogue will be much more important than debate between Europe and the U.S., given some differences in the American and European positions. ${ }^{12}$ But speaking about the European position, the author offers the traditional understanding of Europe as being organized around a so-called German-French "core," and ignores the fact that, since May 2004, ten new countries have been incorporated into the EU, and many of these states have resolutely supported and continue to support the U.S.-U.K. military operation in Iraq.

But what factors were the main reasons for the obvious deterioration of AmericanGerman relations in the early 2000s? The editor of the Frankfürter Allgemeine, Nikolas Busse, has designated this phenomenon as "unprecedented." 13 In his article, "An Estrangement from the Most Important Ally. The Red-Greens and America" ("Die Entfremdung vom wichtigsten Verbündeten. Rot-Grün und Amerika"), he defined three basic problems that could be evaluated as the main reasons for the present deterioration of bilateral relations. These are the refusal of the German government to support the withdrawal of the U.S. from the ABM treaty; the U.S. unwillingness to accept the Kyoto Protocol, along with some other steps that have caused consternation in Berlin; and, last, a disagreement between the partners concerning the military operation

10 Jochen Thies, "Die neue Unsicherheit nach dem Irak-Krieg," Deutschland (2003), 5.

11 Partei des Demokratischen Sozialismus. Programm und Statut (Berlin 1997), 21-23; Bündnis 90/Grünen, Grün ist der Wechsel. Programm zur Bundestagswahl 1998 (Bonn, 1998), 133-54.

12 Joachim Krause, "Multilaterale Ordnung oder Hegemonie?” Deutschland (2003), 14.

13 Nikolas Busse, "Die Entfremdung vom wichtigsten Verbündeten. Rot-Grün und Amerika," in Deutschland im Abseits? Rot-gruene Aussenpolitik 1998-2003, eds. Hans Maull, Sebastian Harnisch, and Constantin Grund (Baden-Baden, 2003), 31. 
against Saddam Hussein. As a result, Busse writes, "Relations between the two countries are worse today than at any point since the end of the Second World War."14

Beyond these objective reasons, which have been analyzed by this and other German authors, it is necessary to indicate at least three subjective causes that have had the most significant influence on American-German relations in the early 2000s.

The first is the strong desire of Chancellor Gerhard Schröder to keep his post after the 2002 Bundestag elections. It is remarkable that, in 1999, the German government not only actively supported the NATO military action in Kosovo, but also directly participated in this operation in spite of the lack of approval from the UN Security Council because of Russia's opposition. The consequence was the relative abstention of pacifist- and leftist-oriented German voters from the European Parliament elections in 1999, and a crushing defeat for the Social Democrats only one year after their victory in the Bundestag elections. ${ }^{15}$

The summer of 2002 also brought the real opportunity of a new defeat for the Social Democrats in the federal elections. Public support for the Christian Democrats and Liberals exceeded the level of support for the ruling coalition. Therefore it was an urgent problem for Red-Green leaders to take a position that would win them public support as soon as possible. The U.S. build-up to military action in Iraq was used by Gerhard Schröder as an inflammatory issue to increase his popularity. And it is necessary to agree with Busse's statement that the more resolutely Washington expressed its readiness to overthrow Saddam, the more rigidly Berlin refused to support this operation. $^{16}$

As a result, the Social Democrats and Greens kept their government, thanks to the support of the anti-war voters (and left the radically leftist and pacifist Democratic Socialist Party shut out of the Bundestag), but they damaged relations with the major German ally. It was a real price of Schröder's second election victory, even as he once again showed his talent for political flexibility.

Second, the earlier generation of modern German leaders were representatives of a so-called "post-war generation," which has particular gratitude to the U.S. as the country that rescued the Western part of Germany from becoming a Soviet protectorate. Moreover, the United States was the strongest supporter of German unification, particularly for such politicians as Helmut Kohl and Hans-Dieter Genscher. So, in a diary of the former Chancellor, dating from 1998-2000, there are some especially cordial memoirs about his friendly relations with former U.S. President George Bush. And Kohl affirmed that this friendship helped to solve such difficult political problems as the form of German participation in the allied operation against Saddam Hussein in 1991. ${ }^{17}$ The former Chancellor also recollected with gratitude that former U.S. President Bill Clinton, who visited Germany in June 2000, met with Kohl even after his

14 Ibid., 19.

15 Hans Georg Lehmann, Deutschland-Chronik 1945 bis 2000 (Bonn, 2000), 573-74.

16 Busse, "Die Entfremdung vom wichtigsten Verbuendeten," 28.

17 Helmut Kohl, Mein Tagebuch 1998-2000 (München, 2000), 258-60. 
resignation and expressed his support in connection with accusations of financial fraud in the CDU. ${ }^{18}$

For Schröder and former "sponti" Joschka Fischer, however, the U.S. is merely an important partner for Germany on the global stage, and for them it is more than possible to disagree with the American point of view. The new leaders of Germany prefer to talk with Washington on a so-called "pragmatic" basis. However, the results of such a dialogue are much worse than the results of the closer level of German cooperation with the U.S. in the period of the Kohl government.

Certainly, this circumstance was not decisive in the process of defining the German position concerning the military action in Iraq, but it is also a mistake to ignore this factor. The level of trust between current U.S. President Bush and Gerhard Schröder is obviously lower than that between Helmut Kohl and his three American partners.

Third, the present German leaders have been influenced by a factor that can be described as "Euroeuphoria." The active pursuit of European integration in the late 1990s and early 2000s, and the increase of the number of EU members from twelve in 1994 to twenty-five in 2004, allowed one to speak of the creation of a new power center of international relations, not only in Europe, but on the global stage. The EU, which today is first of all an economic structure, was envisioned by some European experts as eventually representing a genuine counterbalance to U.S. hegemony in international relations. Thus, Germany and France considered themselves as an engine of this process. Therefore the leaders of these states were fully confident that their position would be particularly crucial for the further development of the European CFSP.

Nevertheless, the first international problem that faced the "EU-25," namely the crisis in Iraq, has demonstrated that there is little if any consensus in the European Union concerning the key questions of international relations. Moreover, the leading role of Germany and France in the process of defining the CFSP's priorities was challenged by other members of the EU.

For example, the Polish leader A. Kwasniewski has declared in an interview for the Russian magazine Itogi that one of the most important reasons behind the political conflict between Poland and Germany as well as France concerning the allied military action in Iraq was the effort on the part of the countries of so-called "old Europe" to impose their will upon post-Soviet states, including their ideas about the necessary level of partnership between the U.S. and these Central and Eastern European countries. Therefore, the Polish President has said that "some necessarily want to rap us a little over the knuckles." 19

The fact that the largest new member of the EU should take such a position, one that is supported by many other European countries, should be given particular attention within the German government. Today it is already obvious that the Eastern European states will first of all pursue their own interests in foreign relations, and therefore will not simply follow the edicts handed down from Berlin and Paris. The negative

18 Ibid., 232-33.

19 “Europe for all” (in Russian), Itogi (18 November 2003), 29. 
legacy of dependence on the Great Powers in 1918-39 and its tragic results are an effective inoculation for these states to not repeat this mistake.

And, finally, it is necessary to analyze some models of the current state of American-German relations according to two different strategies of the German government. Certainly, the most preferable variant would be a return of German foreign policy to the priorities that were defined by the regime of Kohl and Genscher. In that case, the American-German partnership will once again be a key focus of German foreign relations, and after the passage of some years the present problems in the bilateral relationship will be of interest only to scholars of the recent history of international relations. However, it is necessary to note that the probability of this eventuality is directly dependent on the results of the federal election in Germany in 2006, and namely on the likely defeat of the Red-Green coalition.

The second and not so positive variant is a continuation of the current policy of the Federal government. Nowadays, Gerhard Schröder and Joschka Fischer are keeping their eye on the coming Bundestag election, and therefore continue to distance themselves from the American action in Iraq. Thus the Social Democrats and Greens are once again counting on receiving the bulk of the support of the pacifist- and leftist-oriented voters and on repeating their victory along the lines of the approach that was so markedly successful for Schröder and Fischer political scheme 2002. In that case, the current disagreement between the two erstwhile partners will not disappear, but may intensify even more.

In such a situation, an obvious ally for Washington is the German Right opposition, namely the CDU-CSU. Both the present leadership of these parties and representatives of the upcoming generations of the Christian Democrats consider the partnership with the U.S. to be a priority of both German foreign policy and the CFSP.

For example, a charter addressing transatlantic relations in the security sphere is placed as the first in the proposals of a section of the Young Foreign Politicians' "German Foreign Policy in the $21^{\text {st }}$ Century" ("Deutsche Aussenpolitik im 21. Jahrhundert"), a research activity that was sponsored by the CDU Konrad-AdenauerStiftung. And immediately following it are charters devoted to the role of Germany in the EU and world economy, and also to other problems. ${ }^{20}$

Thus, the Young CDU Foreign Politicians consider that a main objective of the further development of the American-German relationship is a return to and securing of the exclusive status of this partnership within the framework of German foreign policy. They also are of the opinion that Germany should again act as an intermediary in relations between the U.S. and Europe and, if necessary, as a military partner of the U.S. within the framework of the ESDP. But the members of this section emphasize that the use of military force is not an a priori means of German diplomacy. ${ }^{21}$

20 "Deutsche Aussenpolitik im 21. Jahrhundert. Vorschläge des 'Arbeitskreises Junger Aussenpolitiker,"' Zukunftforum Politik 53 (Sankt Augustin, April 2003): 5.

21 Ibid., 9. 
Another precondition for the further constructive development of the partnership between the U.S. and Germany is not only the significant influence of some regional leaders on the process of the formation of German internal and foreign policy, but also a gradual strengthening of a role of regions in the new "melting pot" of European integration. Therefore, many leaders of the German Lands (provinces) strive for a close cooperation with the U.S. within the framework of such a "regionalization" of European politics.

As an example of this tendency, we might recall a position of the present head of the Bavarian Government and CSU leader E. Stoiber, who was a main opponent of Social-Democrat Gerhard Schröder during the election campaign in 2002, and sharply criticized the Chancellor's foreign policy strategy towards the U.S. In spite of the defeat of the CDU-CSU, Stoiber was able to represent himself not only as a regional leader, but also as a Federal and European politician. And his opinion in this sphere can be considered as a substantive alternative to the current Red-Green approach to foreign policy.

Recently elected Federal President Horst Köhler, who was a candidate of the Right opposition and former Administrative Director of the IMF, can also exercise a positive influence on the German international activity. ${ }^{22}$ In spite of the limited functions and powers of the President of the FRG, his moderate position would partly counterbalance the point of view of the Federal Chancellor towards the U.S. and the allied operation in Iraq.

In conclusion, it is necessary to emphasize that the present situation in AmericanGerman relations is especially critical not only to the further development of the transatlantic partnership, but also to the formation of a new configuration of international relations in Eastern and Central Europe, which will include my native land of Belarus.

22 "Horst Köhler im ersten Wahlgang zum Bundespraesidenten gewaehlt," available at: http://www.bundestag.de/bic/hib/2004//2004_135/01.html, 23.05.2004. 


\section{Bibliography}

Blettner, Annette. "Bundeswehr Einsatz in Afghanistan." Deutschland (2003): 58-61.

Dembinski, Matthias, and Wolfgang Wagner. "Europäische Kollateralschäden." Aus Politik und Zeitgeschichte (2003).

Deutsche Aussenpolitik im 21. Jahrhundert. Vorschläge des 'Arbeitskreises Junger Aussen-politiker'. Zukunftforum Politik 53 (2003).

Görtemaker, Manfred. Kleine Geschichte der Bundesrepublik Deutschland . Bonn, 2002 .

Hippler, Jochen. "Unilateralismus der USA als Problem der internationalen Politik." Aus Politik und Zeitgeschichte 15 (2003): 17-18.

Kohl, Helmut. Ich wollte Deutschlands Einheit., 2000.

Krell, Gert. "Arroganz der Macht, Arroganz der Ohnmacht." Aus Politik und Zeitgeschichte (2003): 31-32.

Vornbäumen, Axel. "Teamarbeit." Deutschland (2003). 